\title{
法務省旧本館の創建時の床構法に関する研究 \\ A STUDY ON THE FLOOR CONSTRUCTION OF THE OLD MINISTRY OF JUSTICE BUILDING
}

\author{
堀内正昭* \\ Masaaki HORIUCHI
}

\begin{abstract}
This paper deals with the restoration of the floor construction of the old Ministry of Justice building, originally completed in 1895. The building was planned according to the metric system of measurement and is one of the earliest examples of a hoop-iron construction for earthquake protection and with vaults of bricks for fire protection, which were developed after the Nobi Earthquake in 1891. Reinforcement works such as iron beans covered with bricks and reinforced concrete were used in the building. This seems to be because the Nobi Earthquake occurred during the course of construction. The building mainly had single flooring consisting of wood beams placed every about 90 centimeters.
\end{abstract}

Keywords:Floor construction, Earthquake protection, Fire protection, Nobi Earthquake, The Old Ministry of Justice Building 床構法, 耐震, 防火, 濃尾地震, 法務省旧本館

はじめに

筆者は、エンデ\&ベックマン建築事務所によって設計された法務 省旧本館（旧司法省庁舎、創建1888～1895）の創建時の構法を明ら かにするという目的をもって、これまでに、旧本館に耐震構法とし

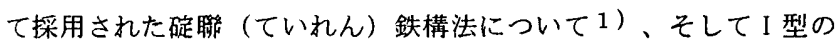
鉄梁を迫元にしてその間に棟瓦のヴォールトをわたしてつくる防火 床構法（ヴォールト煉瓦床）について2）、それぞれ発表し、さら に旧本館の 3 階床の一部の復原を行った 3 )。

法茅省旧本館は、第二次世界大戦で壁と床の一部を残して焼失し、 昭和の復旧工事（1948～1950）で旧状は大幅に変更された。1991年 から1995年に行われた平成の復原改修工事で㓣建時の外観が蘇ると ともに、この平成の解体工事中に、砋聯鉄構法、ヴォールト煉瓦床 のほかに、3階床下から鉄骨を棟瓦で被覆した梁、鉄骨を鉄筋とコ ンクリートで補強した梁が発見された。これらの新たに見出された 梁は、鉄の錆具合や周囲に残る木煉瓦が炭化していたことから（戦 災で床が焼失した証拠）、創建時の遗構と考えられている。

碇聯鉄構法、ヴォールト煉瓦床、そして生子鉄板（旧本館では、 円形階段室の R 階の防火床をつくっていたが、見存せず）は、耐 震・防火床構造として、いずれも濃尾地震（1891）以降に普及した とされる4）。これらの構法がすべて採用された法務省旧本館は、
近代建築技術史上に重要な位置を占めると思われるが、これまで創 建時の構法については十分な解明はなされなかった。

ところで、旧本館の床構法については、「司法省三階鉄梁及木梁 共据付方仕様注文」という詳細な建築仕様の記録が残されている。 それは、建築史家の関野貞（1867 1935）が書き写したものであり 5)、構法を具体的に解明寸る上で重要な内容を含んでいる。

そこで、本稿では、同建築仕様の一部始終を解読することとし、 遗構ならびに創建時の図面の分析を通して、とくに法務省旧本館の 3 階床の復原を試みていく。

なお、旧本館の床棈法の関連図として、次の創建時の図面が法務 省に所蔵されている。

・「司法省初階梁配置之図」

旧本館の 2 階床梁の伏図である。

・「司法省主要寸法押さえ 3 階平面図」

3 階諸室の寸法、壁体に㨂入された碇聯鉄の位置および寸法が記 入されている。

・「2階ホールの断面図」

2 階円形階段室前のホールの縦断面図であり、1891年 7 月の日付 とリヒャルト・ゼール(1854〜1922) の署名がある。

・「階段室平面詳細図」 


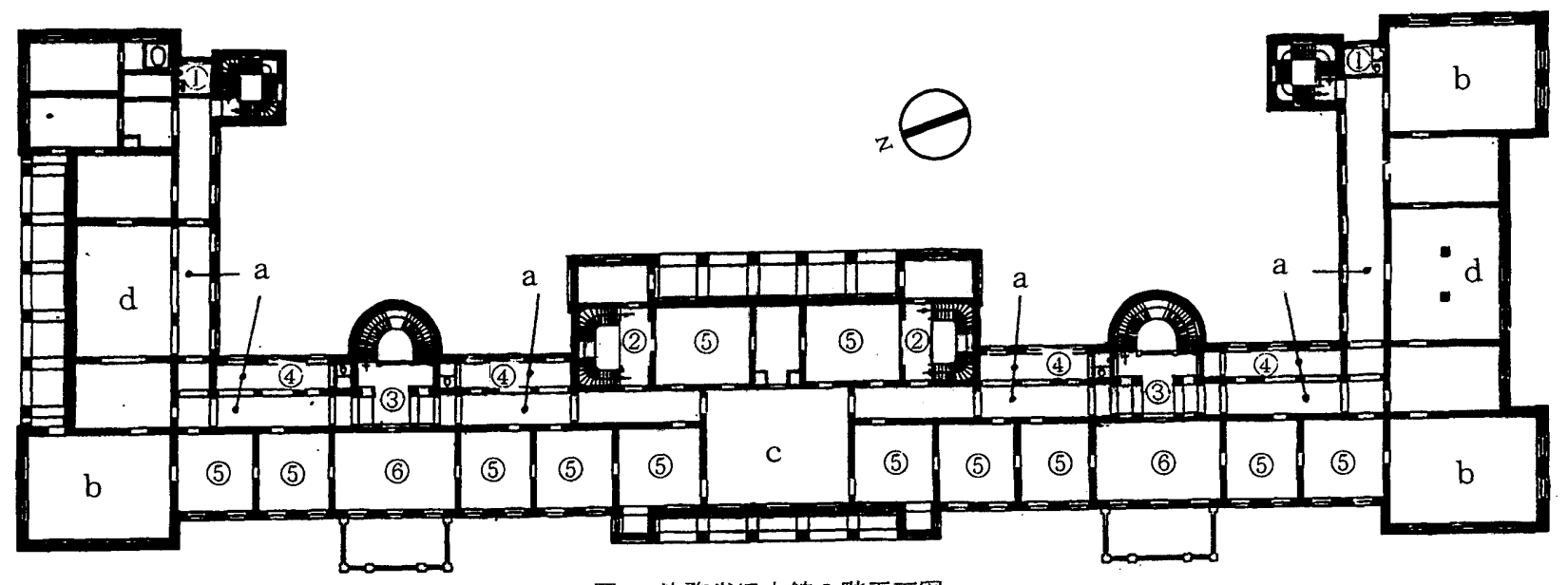

図 1 法務省旧本館 3 階平面図

旧本館の中央棟に設けられた階段室の 2 階から 3 階の踊場までの 平面図で、隺梁の位置と寸法が記入されている。

以上の図面に共通寸るのは、いずれもメートル法で設計されてい るということである。

\section{I 、司法省三階鉄梁及木梁共据付方仕様注文}

本仕様畵には、3 階床の鉄梁と木梁の寸法と数、そして使用個所 が記載されるとともに、主として「廊下通其他」、「隅々広間」、 「中央広問」、そして「両側中央広間」に関する仕様が示される。 さらに、構法の図解スケッチ（図 7) がつくが、本仕様の部材寸法 は寸べて尺寸で表示されている。以下、順に内容を検討していく。

\section{a) 廊下通其他（図 1 の平面図 a 部分）}

本個所の記述は、旧本館の廊下通りに関寸るもので、内容は次の 3点に要約される。

(1颜下通りその他は、鉄梁を 3 尺 5 寸あるいは 5 尺以内に割り付 ける。

(2)鉄梁は、迫持受梁として用いる。

(3)鉄梁の寸法と本数

長11.22尺 $(3,400 \mathrm{~mm}) \times$ 成 5.94 寸 $(180 \mathrm{~mm})$ のもの 77 本 長9.075尺 $(2,750 \mathrm{~mm}) \times$ 成 4.64 寸 $(141 \mathrm{~mm})$ のもの 20 本 (なお、番号(1)(2)は等者が任意につけ、 $\mathrm{mm}$ 自换算も笋者が行 った。以下同じ。)

旧本館の3 階の廊下通りは、ヴォールト煉瓦床でつくられ、平成 の解体工事中に中央棟から北側に 34 本、南側に 35 本の計 69 本 の鉄梁が確慧できた6)。(図 2) これら現存するI型鉄梁は、平均 して約 $1,450 \mathrm{~mm}$ で割り付けられていた。

廊下の内法幅は、中央部、両翼部とも $3,000 \mathrm{~mm}$ なので、2 種類 の鉄梁のうちでは長 $3,400 \mathrm{~mm}$ のものが使用されたことになる。計 77 本の鉄梁加既存の 69 本を引いた残り8本の位置については、 (1)再翼部の廊下の突き当たりにある小部屋(便所)、(2)中央棟両側 にある階段室の趾場、(3)形階段室前のホールの3 所が候補とな ろう。これらの諸室は、いずれも昭和の復旧工事で改修された。

まず小部屋（図1の(1)）については廊下と同じ幅をもっているの で、ヴォールト棟瓦床で仕上げられたのであれば、鉄梁は1 本入る。

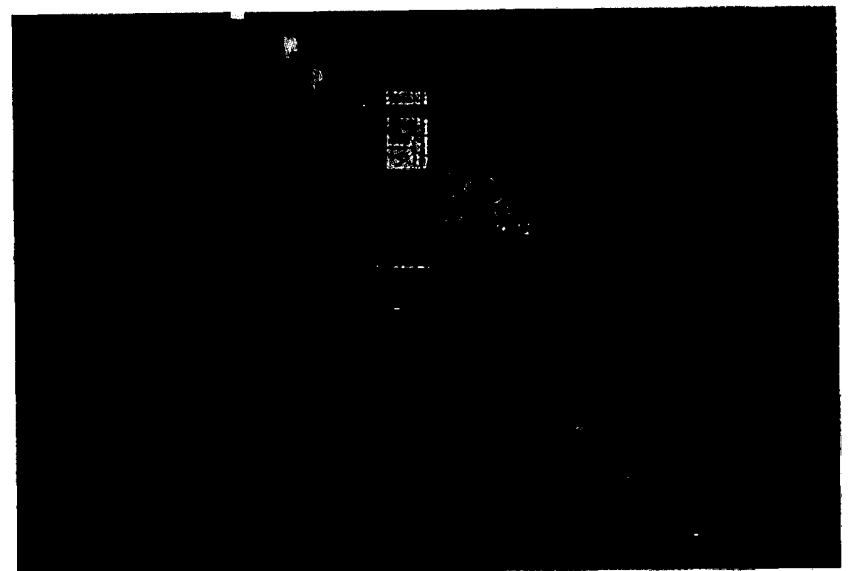

図 23 階廊下のヴォールト棟瓦床（復原改修工事中の写真）

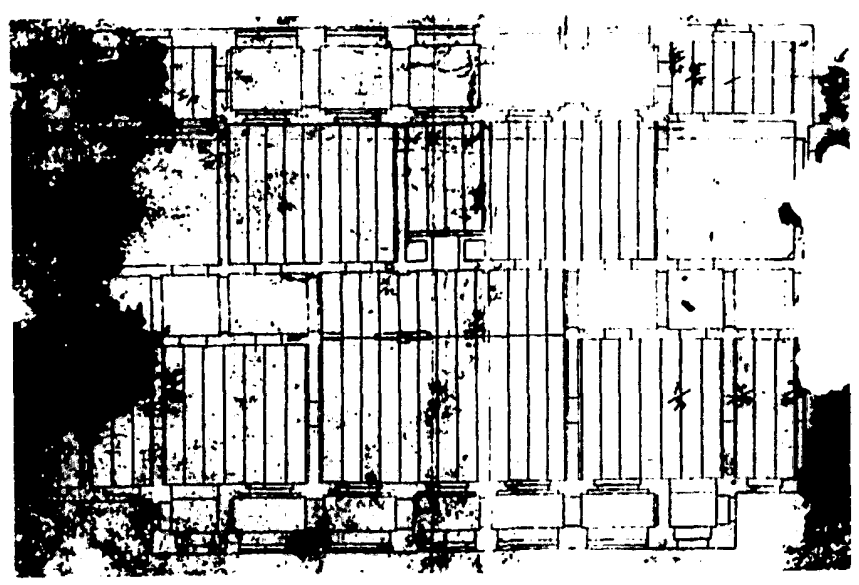

図 3 旧本館㓣建時の 2 階床伏図（図は中央棟部分）

しかし、旧本館の創建時の 2 階の床伏図「司法省初階梁配圈之図」 （図３）を見ると、同図の再翼部の端にも便所があり、ここは单床 である。2 階と 3 階の便所の仕椂を異にしたとは考えにくいので、 3 階の便所も単床であったと思われる。

次に、階段室の踊場（図1の(2) については鉄梁の嗐入と、ドイ

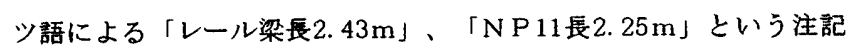
がある（図4）。NPとは、Normal Profil（規格形）の略であり、 この場合の N P 11 とは、鉄梁の成が110 m mのものを指す。仕様萧 に記載された鉄梁の成は $180 \mathrm{~mm}$ 、つまり N P 18であり、階段室用 


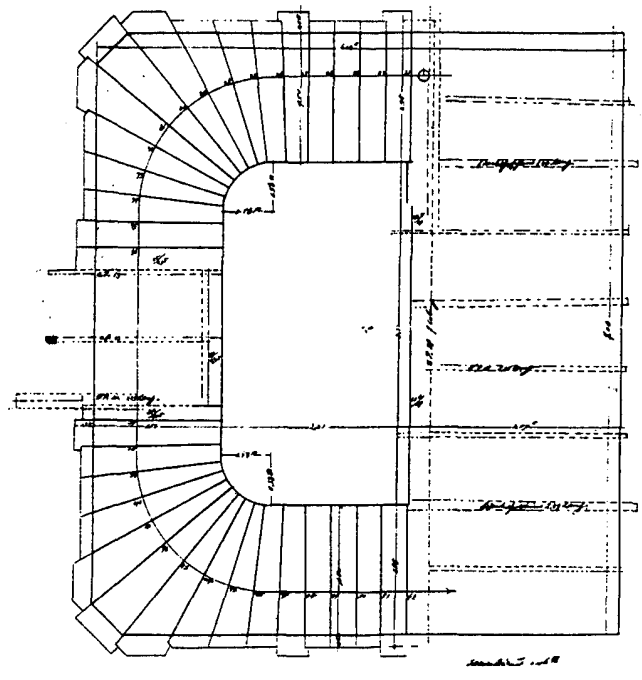

図 4 旧本館㓣建時の 3 階階段室踊場

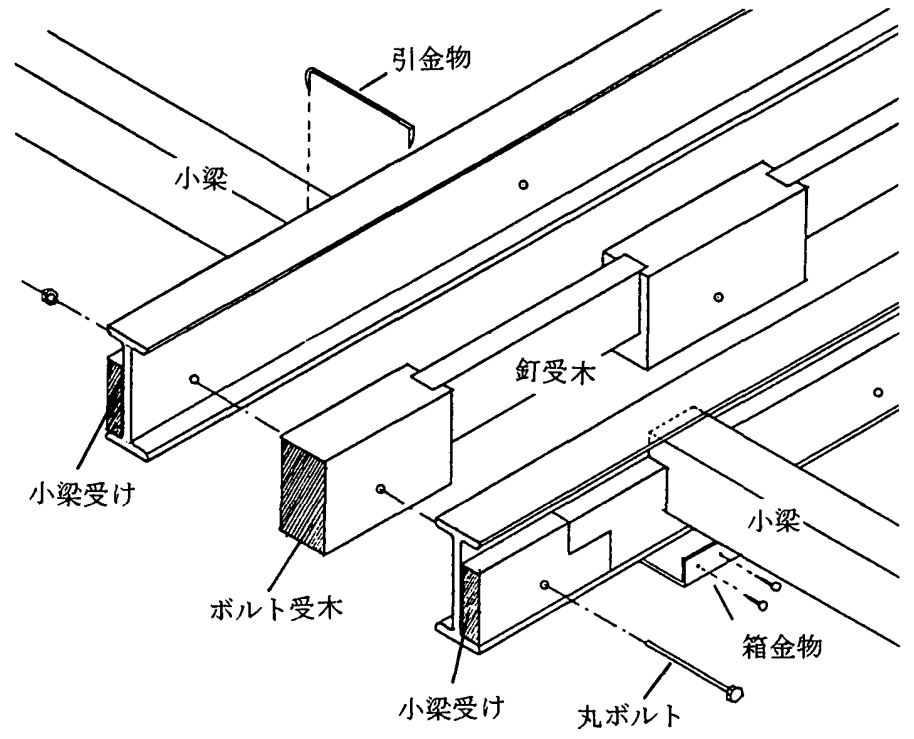

図 6 隅々広間の合せ梁の構法図解

のものではなかったことになる。また、同図には鉄梁 8 本の表示が あり 7)、鉄梁の間隔は約 $800 \mathrm{~mm}$ となる。仕様書には、鉄梁の間隔 が 3 尺 5 寸あるいは 5 尺とあるので、踊場は、仕様書とは別の仕様 でつくられたことになる。

では、円形階段室前のホール（図1の(3) はどうか。同ホールの 断面を示す創建時の図面（図 5) には、ヴォールト煉瓦床の断面表 示は見られない。

以上から、長 $3,400 \mathrm{~mm}$ の鉄梁 77 本の数は、実際の施工とは合致 しない。復原に際しては、既存の 69 本のままと寸るほか、階段室 踊場については、図面通りに 8 本の鉄梁が配置されていたものとす る。

他方、長 $2,750 \mathrm{~mm}$ の鉄梁については、内形階段室に隣接する諸 室（昭和の復旧工事で改修、平面図 1 の(4)）の内法幅が2, $350 \mathrm{~m} \mathrm{~m}$ であること、仮に 5 尺で鉄梁を割り付けてみると、それぞれ 10 本 ずつ計 20 本の鉄梁が入ることから、同部分については、仕様書通 りに施工されたと考えられる。

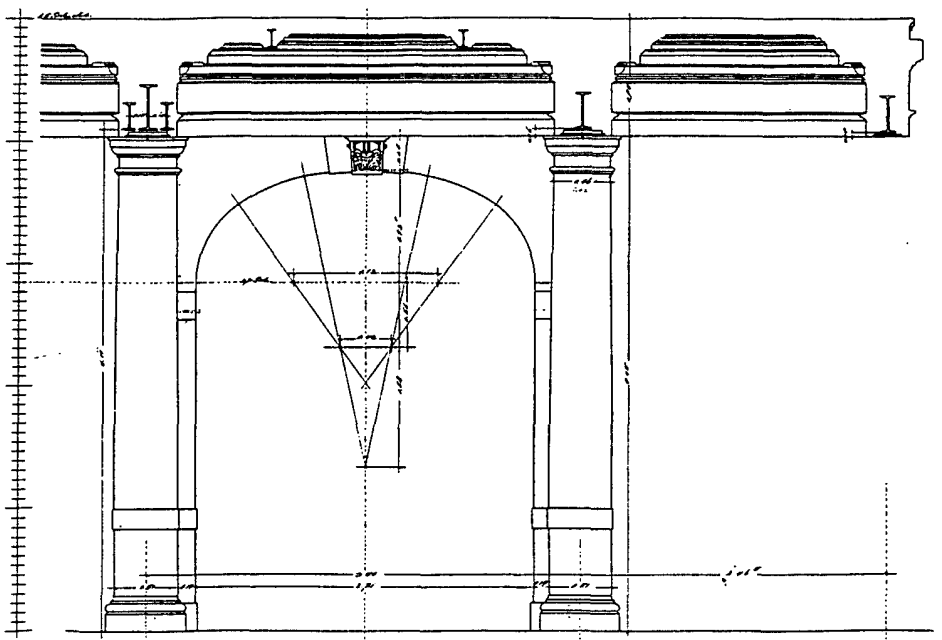

図 5 旧本館㓣建時の 2 階ホールの断面図

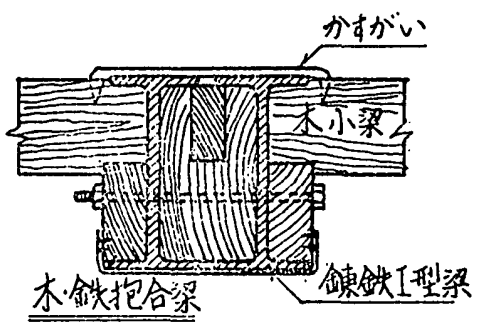

図 7 関野 貞による合せ梁の構法図解

b ）隅々広間（図 1 の平面図 b 部分）

本個所の記述は、旧本館の北西、南東、そして南西端に位置する 計 3 ケ所の広間についてのものである。

(1)鉄梁は合せ梁とする：長 34.122 尺（10,340 m m) ×成1.188尺 $(360 \mathrm{~mm})$ のもの 12 本

(2)合せ梁の左右に桧材の小梁受けを入れ、小梁受け 1 本につき 8 分 丸ボルト 4 本で止める。小梁受け：長15尺 $\times$ 成 8 寸 $\times 3$ 寸

(3)合せ梁の中にボルト受木を㯰く：長 2 尺内外

(4)床板釗受木をボルト受木と慗ぐ : 長さ任意、成 7 寸 $\times 3$ 寸 (5)床板釘受木の幅は1 寸で、ボルト受木とは大入れにして慗ぐ。 (6)合せ梁と小梁は、箱金物でビス止めする。

(7)小梁は長13.2尺と長21.5尺のものを小梁受けに久込みにする。 (8)左右の小梁は、引金物で止める。

(9)梁の本数と寸法

小梁 54 本：13尺 2 寸 $\times 7.5$ 寸 $\times 5.5$ 寸

同・際梁 12 本：13尺 2 寸 $\times 7.5$ 寸 $\times 4.5$ 寸

同・小梁 27 本：11尺 2 寸 $\times 7.5$ 寸 $\times 5.5$ 寸

同・際梁 6 本: 11 尺 2 寸 $\times 7.5$ 寸 $\times 4.5$ 寸

以上から、小梁は長短 2 種類あり、それぞれの合計は際梁を含め て、長13尺 2 寸 $(4,000 \mathrm{~mm})$ のものが 66 本、長11尺 2 寸 $(3,394$ $\mathrm{mm})$ のものが 33 本となる。これらの本数は 3 筒所の広間の合計 なので、一部屋当りは、長 $4,000 \mathrm{~mm}$ のものが 22 本、長 $3,394 \mathrm{~mm}$ のものが 11 本となる。したがって、各広間は合せ梁を 2 本わたし て、その間に 11 本ずつの小梁をかけてつくられたことになる。 
次に、この種の合せ梁を用いた実際のスパンを計算してみよう。 長4, $000 \mathrm{~mm}$ の梁が 2 本、長3, $394 \mathrm{~mm}$ のものが 1 本で、計 $11,394 \mathrm{~mm}$ 。 これにボルト受木と鉄梁の幅を加え、小梁の欠込み分を引けばよい。 ボルト受木の幅を 1 尺、鉄梁の幅は精々 1 寸と見皟もって概算する と、最長の場合でも $12 \mathrm{~m}$ を越えない。

ところが、該当する広閒の内法幅は $12,520 \mathrm{~mm}$ なので、架け渡す にはスパンが足りない。そこで、上記箇条書きの表の(7)長 21.5 尺 $(6,515 \mathrm{~mm})$ の小梁を使うと、合計は $16 \mathrm{~m}$ を越え、今度はスパン を大幅に超過してしまう。いずれにせよ、本広間に関寸る仕様は、 見実に照らせば不正確である。

以上を図解したのが図6であり、関野貞による䆏法図（図 7) は 本広間のものであったことがわかる。

c）中央広間（図 1 の平面図 c 部分）

本個所は、中央棟のバルコニーに面する広䦌である。

(1)杉材の数梁を煉瓦壁に架けわたす。

(2小梁を合欠きにして数梁上で慗ぐ。

(3)敖梁と小梁の本数と寸法

䑤梁 2 本: 42 尺 6 寸 $\times 1$ 尺 3 寸 $\times 9$ 寸 5 分

同・小梁 12 本：25尺 4 寸 $\times 1$ 尺 $\times 7$ 寸

同・際梁 2 本：25尺 4 寸 $\times 1$ 尺 $\times 4$ 寸 5 分

同・小梁 12 本：12尺 $\times 1$ 尺 $\times 7$ 寸

同・際梁 2 本: 12 尺 $\times 1$ 尺 $\times 4$ 寸 5 分

広間の寸法は、間口が心々で12, $900 \mathrm{~mm}$ なので、この方向に長 42 尺6寸 $(12,909 \mathrm{~mm})$ の教梁が 2 本入る。同広間の梁行方向の幅は、 心々で10,920 $\mathrm{mm}$ なので、この方向に長 25 尺 4 寸 $(7,697 \mathrm{~mm})$ と 長12尺 $(3,636 \mathrm{~mm})$ の小梁を慗げば架けることができる。

ところで、同広間の床下には 2 階から廊下通りにある煉瓦壁がく る。ここに教梁の 1 本を置くと、この数梁からそれぞれの壁までの スパンは心々で、7,520 $\mathrm{mm}$ と $3,400 \mathrm{~mm}$ となり、仕様書に記載され た小梁の長さに見合う。

なお、もう 1 本の数梁は、この広間を 3 分割する点にとることに した。

d) 両僋中央広間 (図 1 の平面図 $\mathrm{d}$ 部分)

旧本館の北翼部と南翼部の中央に、それぞれ広閏があり、それぞ れのスバンは、心々で8,900 $\mathrm{mm}$ と $10,150 \mathrm{~mm}$ である。

長33尺 5 寸 $\times 1$ 尺 3 寸 $\times 9$ 寸 5 分の数梁を用いる。

長33尺 5 寸 $(10,152 \mathrm{~mm})$ に見合うスパンをもつのは、南翼部の 方である。本数の記載がないが、復原に際しては、本広間の中央の 床下に独立柱が 2 本あったので、この柱上に 2 本の敷梁を置くこと にした。

なお、北翼部にある広間については、同広間が 2 階の同筬所の広 闑と同じ大きさをもっていることから、2 階と同様に梁閒方向に根 太をわたした単床として復原した。

II. 木梁の配置について

前節においては、「司法省三階鉄梁及木梁共据付方仕様注文」の うち説明書きのある諸室について検討したが、本仕様畵には、木梁
に関して別に次の記述がある

正面中央廊下左右の各間；

木梁 76 本：長 24.6 尺 $\times 1$ 尺 $\times 7$ 寸

同際梁 24 本 : 長 24.6 尺 $\times 1$ 尺 $\times 4.5$ 寸

際梁が 24 本ということは、各室に 2 本入るとして、1 2 室分に 相当寸る。正面中央廊下に面寸る左右の部屋としては、廊下通りの 西側に並ぶ諸室ならびに中央階段室に面する計 12 部屋が候補にな ろう。(図 1の(5)

次に木梁の張間については、旧本館の 2 階の床伏図（図3）から 梁は約 $900 \mathrm{~mm}$ で配置されていた。そこで、同図を参考にして 3 階 床の梁を割り付けてみると、3 階の 12 部屋に木梁 76 本と際梁 2 4 本、計 100 本の梁が入ることがわかった。

ところで、仕様畵には別に木梁の合計は 373 本と書かれ、その うち枕梁は 3 本とある。枕梁は、伏図に現れないので、木梁の総数 は、これを除いて 370 本となる。しかし、3階の床に約 $900 \mathrm{~mm}$ で木梁を割り付けてみると、400本以上の梁が必要となった。因 みに、図 3 の 2 階床の梁を数えると丁度 370 本であった。木梁の 数については、誤記の可能性がある。

III. 娻瓦被覆梁と鉄筋コンクリート補強梁について

鉄骨を棟瓦で被覆した梁、そして鉄骨を鉄筋とコンクリートで補 強した梁は、円形階段室のホールに接する 3 階広間の床をつくって いた（図1の(6)、図 8)。また、3 階広間と廊下との境に、I 型鉄 の合せ梁が使用されていた。

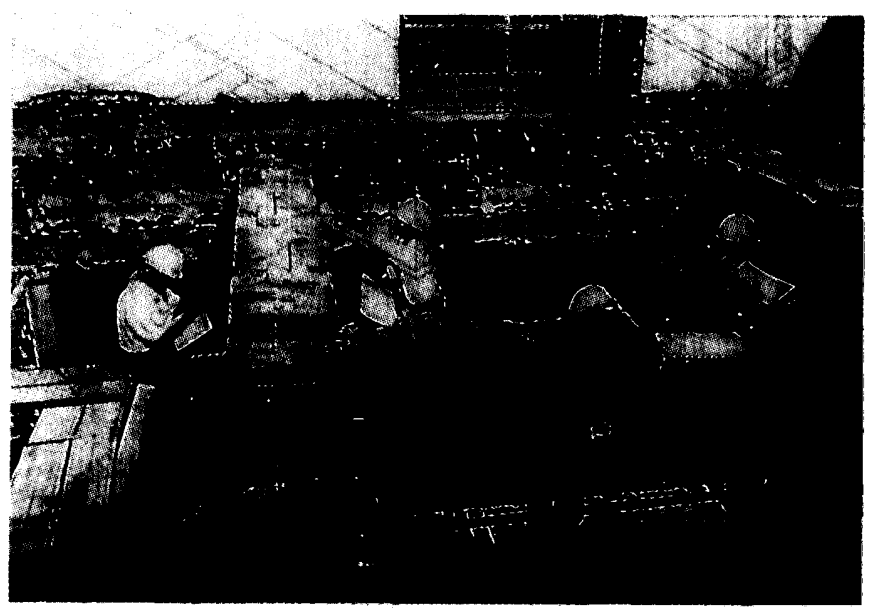

図 83 階広間の棟瓦被覆梁（奥の壁が隌下側）

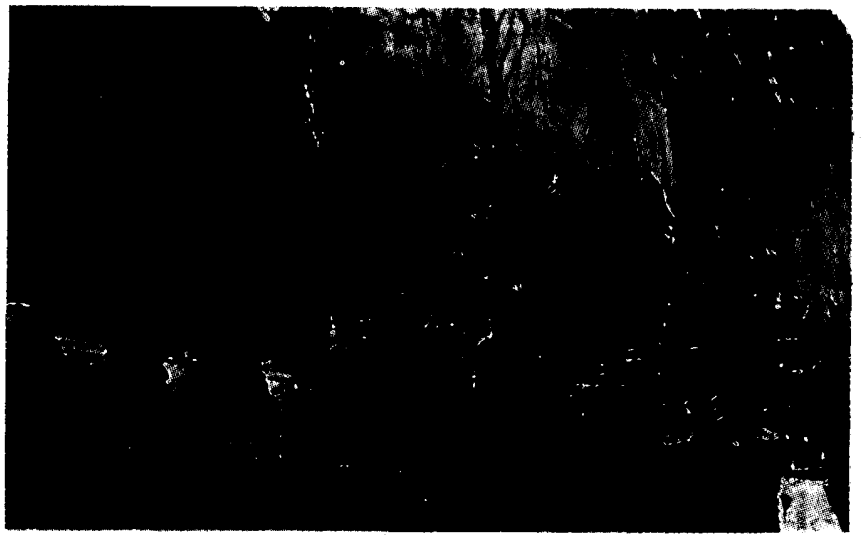

図 9 棟瓦で被覆された鉄梁 


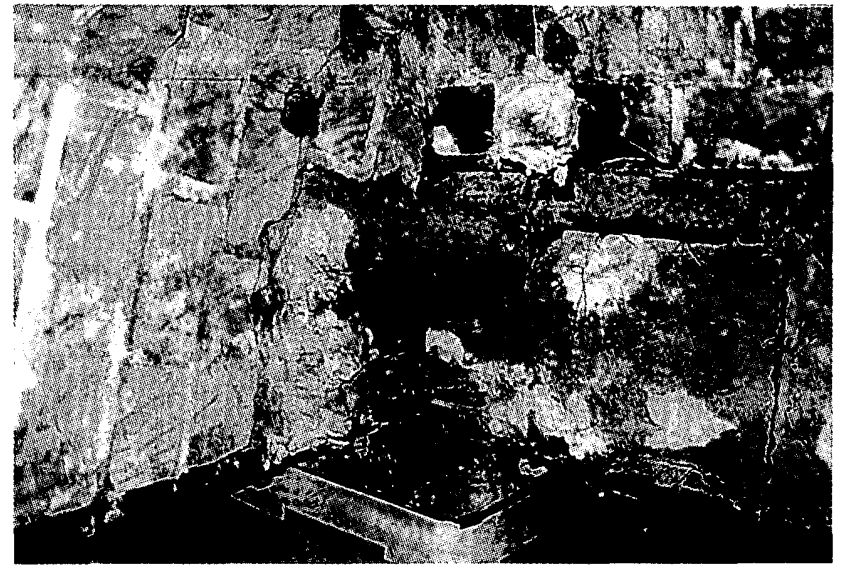

図 10 鉄筋コンクリートで補強した鉄梁

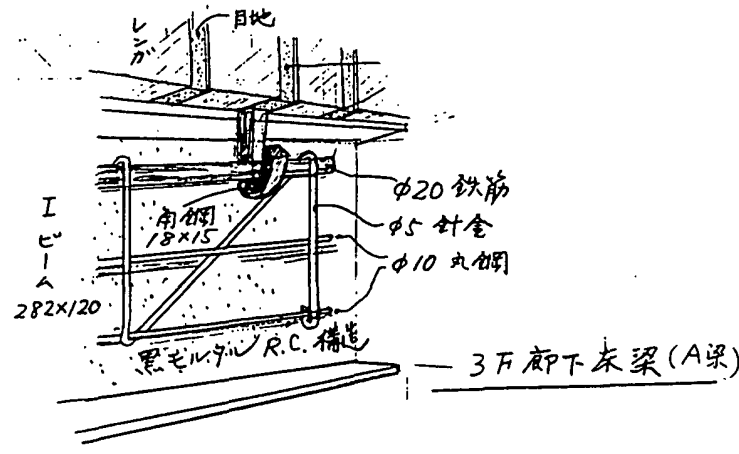

図 11 同・図解 (法政大学工学部建築学科村松貞次郎研究室 の実測調査による)

鉄骨を棟瓦で被覆した梁（図 9 ）は、「棟瓦は鉄骨梁を覆うよう に、繸に中心から左右にアーチ状に積まれ、梁出隅に沿って入れら れた角鋼を丸鋼で幅止めし、れんが繸目地ごとに鉄線で吊って補 強」されていた8)。

他方、鉄骨を鉄筋とコンクリートで補強した梁（図１０、１１） は、I 型鉄梁を 2 本合わせ、その両側に、針金 (径 $5 \mathrm{~mm}$ )、鉄筋 (径 $20 \mathrm{~mm}$ ) 、丸鋼(径 $5 \mathrm{~mm}$ ) を、それぞれ縦、横、斜めに組ん だ枠をつくり、これにコンクリートを打設したものであった9）。

この鉄筋コンクリート補強梁の位置は、旧本館の 2 階ホールの断 面図（図 5) では、柱上に大小 3 本の鉄梁の畫き込みがあるところ に硋当するので、図面と実際の施工は異なっていたことがわかる。

ところで、同断面図には、エンデ\&ベックマン建築事務所の所員 で本館の工事監督を務めたリヒヤルト・ゼールの署名と1891年 7 月 の日付がある。1891年(明治24年) とは濃尾地震の起こった年であ る。同地震が旧本館に及ぼした影響については、「明治 24 年 10 月28日の濃尾地震の時は、司法省建築工程は既に 3 階空上に達し居 りしも何等損害なかりき。然りといえども大震に鑑み、爾来セメン ト及び鉄材を增加し、専ら耐震の方法を講じ、其の他従来の建築方 法にも注意を加えたり。」10）という記述がある。

ゼールの図面は、濃尾地震以前のものである。図面と施工の仕様 が異なったのは、地震直後に設計変更がなされた結果であり、この 場合になされた耐震の工夫こそが煉瓦被覆梁と鉄筋コンクリート補 強梁を生み出したと考えられる。

以上の考察に、碇聯鉄構法の配置を示寸図（図１２）を加えて、 法務省旧本館の 3 階床の復原図を作成した（図１３）。これまで、

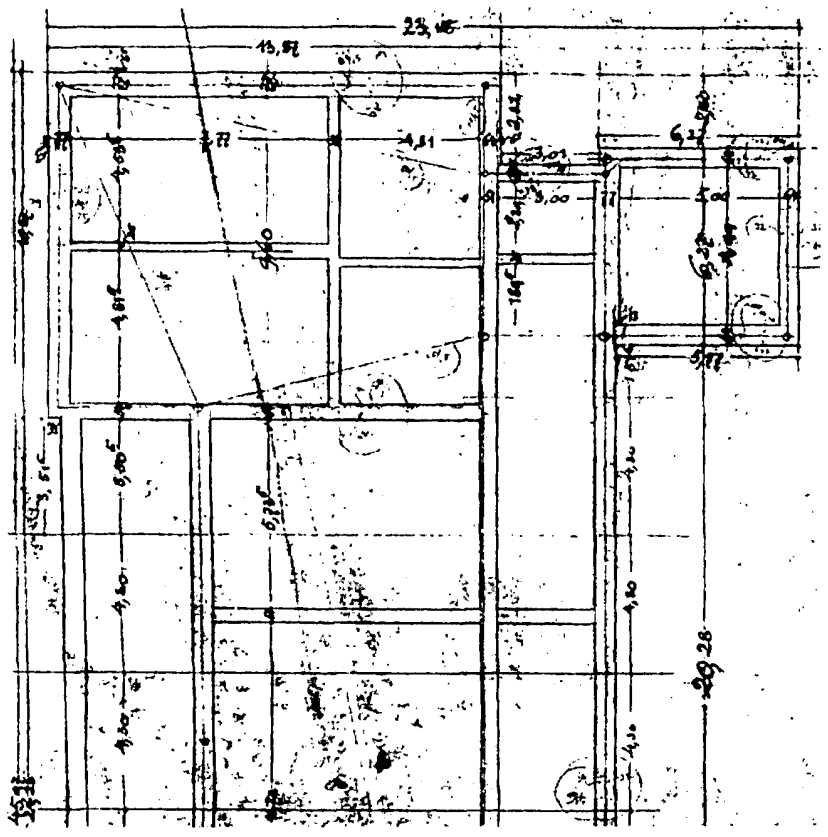

図 12 旧本館創建時の 3 階の礎聯鉄配置図（図は北翼部分）

碇聯鉄構法については、「壁真に1本の帯鉄を敷き聯ね、壁体の交 差部において垂直方向の鉄棒で带鉄を碇着させるもの」１１）とさ れてきたが、図 12 では、帯鉄は壁真のみならず、壁体を離れて斜 め方向にも配筋されている12)。

結 語

関野貞が書き写した「司法省三階鉄梁及木梁共据付方仕様注文」 は、I型鉄梁の本数、「隅々広間」に用いられた小梁のスパン、木 梁の総数など、実際に照らせば合致しない内容を含んだものであっ たが、法務省旧本館の復原作業を通じて、床構法については次のよ うに要約できる。

(1)法務省旧本館の床構法に関する図面はメートルで寸法がとられ、 「司法省三階鉄梁及木梁共据付方壮様注文」では、部材寸法は尺で 畫かれていた。このことから、エンデ\&ベックマン建築事務所では メートル法で設計し、実際の施工は尺で行ったと考えられる。

(2)旧本館の通路部分はヴォールト棟瓦床でつくられ、I 型鉄梁は平 均して約 $1,450 \mathrm{~mm}$ で割り付けられた。ただし、踊場における鉄梁 の張間は約 $800 \mathrm{~mm}$ であった。

(3)木造床は、基本的に張間約 $900 \mathrm{~mm}$ の単床であったが、「中央広 間」、「隅々広間」、南翼部の「中央広間」については複床であっ た 13 3)。このうち、「隅々広間」の大梁は I 型鉄の合せ梁でつく られた。

(4)これまで碇聯鉄構法については、帯鉄は棟瓦壁の中にのみ挿入さ れたと考えられていたが、旧本館の四隅の部屋のコーナーに見るよ うに、旧本館では火打ち梁のごとく斜めにも配置されていた。

(5)棟瓦被覆梁と鉄筋コンクリート補強梁は、旧本館の工事中に経験 した濃尾地震に対して、急遽なされた設計変更による耐震補強の結 果であったと考えられる。

(6)鉄筋コンクリート構造が我が国に導入され、実用化されはじめる のは明治 30 年代半ばであったとされるが 14 ）、旧本館の鉄筋コ ンクリート補強梁は、稚拙な段階にあるとはいえ、その萌芽が確実 


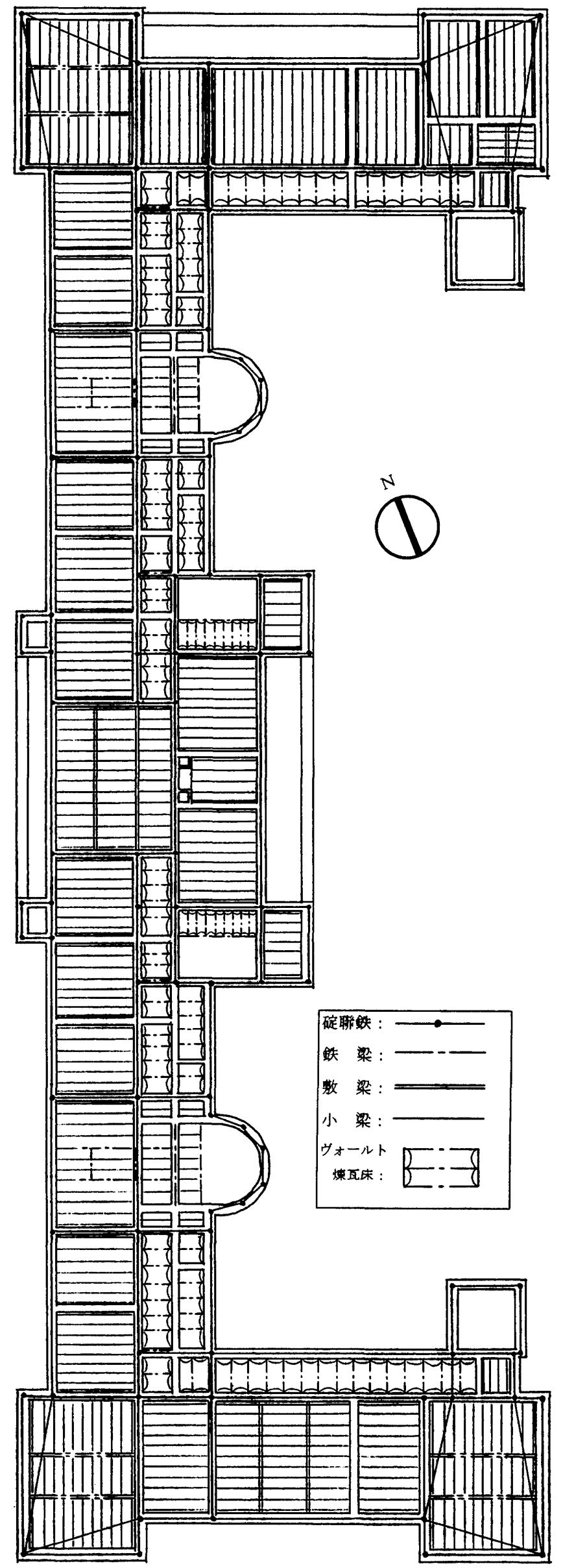

に現れていた事例となる。

なお、本研究は、平成 10 年度文部省科学研究費補助金 基盤研 究 (C) (2) 09650709 の成果の一部である。

期

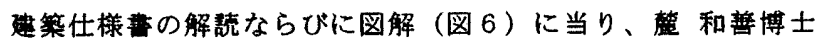
(名古屋工業大学工学部助教授) からご指荋いただきました。ここ に記して感謝申し上げます。

註

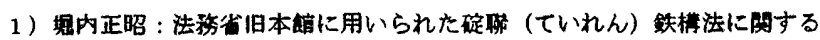

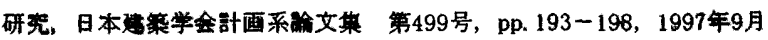

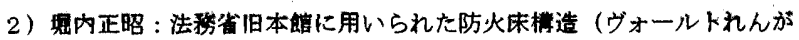
束）について，日本建策学会大会学術曝演梗概集，pp. 19-20,1996年9月

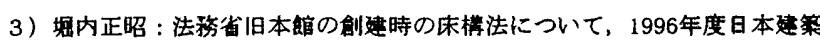
学会関東支部研究報告集, pp. 433-436 本研觉恃、同研究報告集ならび に1997年度建策史学会大会にて「法䇨少旧本能の創建時の满法について」 と斟して行った口頭発表の内容に新たな知見を加えたものである。 4）14）㚏照，日本科学史学全編：日本科学技術史大系 第 17 巻 建策技

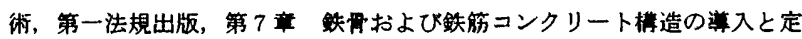
着, pp. 329-334，1964／虫面良：「媡瓦・铁・コンクリート小，建策 雓誌 Vol. 95 No. 1160, pp. 11-13, 1980. 2

5)二の関野兵の手写本怯、次の文献に再緑されている。日本科学史学会 編 : 前揭音, pp. 325-326

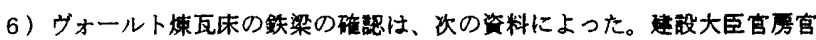

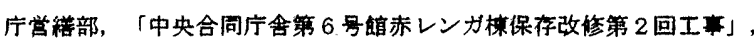
1991年12月

7) 管者は、既発表睮女（砫3）において图 4 (本文)に鉄梁の注記が 3 個

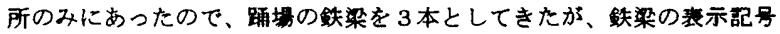
(点線) は他の 5 個所も同一であること、約 $800 \mathrm{~mm}$ の間隭をもつヴォール 卜煤瓦床は当時のドイツでは一般に用いられていたことから、8本に訂正 する。

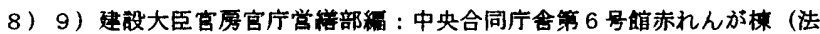
弱省旧本館）保存改修記録，pp. 189-190，1995年3月

10）工学会編：明治工業史建策筑，p. 201，1930年改版（初版1927）

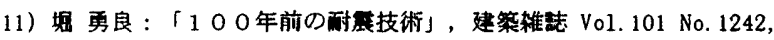
p. $36,1986.1$

12）3階床下の斜め方向の带铁はすでに失われていたが、平成の很原改修工 亭中に、旧本館の南西端にある広間の1階床下から、本文図 12 と同しく 斜め方向に挴入された带鉄が胃出された。

13）旧本館の体組には、振れ止めと算き止めの橉法が用いられていた。

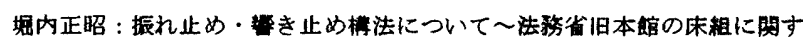
万研究，1997年度日本建筑学会関東支部研究竍告集，pp. 529-532 振れ 止めを含んだ旧本眝のさらに詳細な椿法については、稿を改めて発表する 予定である。

図版出典：図 1建筑雓誌（No.113, 明治29年5月）／図 2, 図8, 図10

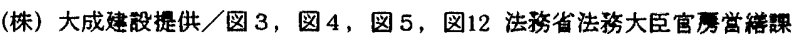

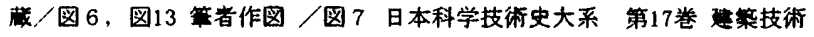

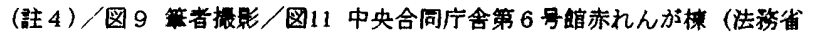

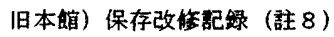

図 13 旧本館創建時の 3 階床伏復原図

（1998年 4 月 7 日原稿受理, 1998年10月22日採用決定 